Jurnal Ilmu-Ilmu Peternakan 26 (1): 29 - 36

ISSN : 0852-3681

E-ISSN : 2443-0765

CFakultas Peternakan UB, http://jiip.ub.ac.id/

\title{
Pengaruh penambahan tepung kulit bawang terhadap kecernaan protein kasar pakan, pertambahan bobot badan dan persentase karkas itik Mojosari
}

\author{
Yoseph Avian Saputra, Istna Mangisah dan Bambang Sukamto \\ Fakultas Peternakan dan Pertanian Universitas Diponegoro \\ Kompl. drh. R. Soejono Koesoemowardojo-Tembalang, Semarang Kode Pos 50275 \\ yosephavian94@gmail.com
}

\begin{abstract}
This study aimed to determine the effect of addition of onion skin flour (OSF) and garlic skin flour (GSF) on feed digestibility of crude protein, body weight gain and carcass percentage of Mojosari ducks. The research used 168 Mojosari duck males aged 4 weeks and had an average weight of $335.5 \pm 72 \mathrm{~g} / \mathrm{duck}(\mathrm{CV}=7.8 \%)$. The study used completely randomized design with7 treatments and 4 replications (T0 $=$ basal feed (BF); T1 = BF + 3\% OSF; T2 = BF+ 6\% OSF; T3 = BF+ 3\% GSF; T4 = BF+ $6 \% \mathrm{GSF} ; \mathrm{T} 5=\mathrm{BF}+1.5 \% \mathrm{OSF}+1.5 \% \mathrm{GSF}$; and $\mathrm{T} 6=\mathrm{BF}+3 \% \mathrm{OSF}+3 \% \mathrm{GSF})$. The results showed that the protein digestibility was found higher $(\mathrm{P}<0.05)$ in T6 $(80.08 \%)$ than T0 (74.76\%), T1 (73.71\%), and T2 (75.54\%). Meanwhile, protein digestibility of $\mathrm{T} 4(79.26 \%)$ were higher $(\mathrm{P}<0.05)$ than $\mathrm{T} 1 \quad(73.71 \%)$. Another findings showed that body weight gain of T0 (15.88 g) were lower ( $\mathrm{P}<0.05)$ than T1 (18.48 g); T2 (18.42 g); T3 (17.96 g); T4 (19.77 g); and T6 (19.05 g). The addition of OSF and GSF could not influence $(\mathrm{P}>0.05)$ the duck carcass percentage. The study concluded that the addition of $6 \%$ GSF and combination of 3\% OSF + 3\% GSF could improve crude protein digestibility and weight gain, but was not able to increase the percentage of duck carcasses.
\end{abstract}

Keywords: duck, digestible protein, body weight, carcas

\section{PENDAHULUAN}

Itik merupakan salah satu jenis unggas yang memiliki kontribusi dalam menyediakan protein hewani berupa telur dan daging bagi masyarakat. Berbagai macam penelitian telah dilakukan untuk meningkatkan rendahnya produktivitas itik, salah satunya dengan memberikan perlakuan pada pakan itik yang bertujuan untuk meningkatan nutrien pakan, meningkatan kecernaan, maupun meningkatan kesehatan itik.

Bawang merupakan tanaman yang telah dikenal masyarakat sebagai tanaman yang memiliki banyak khasiat, salah satunya sebagai obat. Kandungan fitokimia berupa flavonoid, fructans, organosulfur dan saponin pada bawang memiliki peran penting sebagai antioksidan dan antibakteri yang bermanfaat bagi kesehatan. Disisi lain, kulit bawang merupakan limbah yang belum banyak dimanfaatkan. Skerget et al. (2009) menyebutkan bahwa kandungan fitokimia pada kulit bawang lebih tinggi daripada bagian umbinya. Hal ini menunjukkan bahwa penambahan kulit bawang pada pakan berpotensi meningkatkan produktivitas itik dengan harga yang relatif murah. 
Jumlah pemberian tepung kulit bawang akan menentukan jumlah antioksidan dan antibakteri yang terkonsumsi oleh itik. Pemberian 1,25-5\% tepung bawang putih pada pakan belum memberikan pengaruh nyata terhadap konsumsi pakan, pertambahan bobot badan, dan konversi pakan (Saleh, dkk., 2006). Oleh karena itu, perlu dilakukan penelitian yang menggunakan kulit bawang pada konsentrasi yang lebih tinggi dengan harapan dapat meningkatkan kandungan antioksidan dan antibakteri dalam pakan sehingga dapat meningkatkan kesehatan dan produktivitas itik. Peningkatan kesehatan dimungkinkan akan meningkatkan tingkat kecernaan protein kasar, sehingga mendukung pembentukan daging yang dapat dilihat dari pertambahan bobot badan dan persentase karkas. Penelitian ini bertujuan untuk mengetahui pengaruh penambahan tepung kulit bawang pada pakan terhadap kecernaan protein kasar, pertambahan bobot badan, dan persentase karkas itik Mojosari.

\section{MATERI DAN METODE}

Penelitian ini dilaksanakan pada bulan Oktober-November 2015 di kandang digesti Fakultas Peternakan dan Pertanian Universitas Diponegoro. Materi penelitian menggunakan itik Mojosari jantan sebanyak 168 ekor berumur 4 minggu dan bobot rata-rata 335,5 \pm 72 g/ekor (CV = 7,8\%).

Pakan tersusun dari jagung giling, dedak padi, tepung ikan, bungkil kedelai, $\mathrm{CaCO}_{3}$, premix, tepung kulit bawang merah (TKBM) dan tepung kulit bawang putih (TKBP). Pembuatan tepung kulit bawang merah dan tepung kulit bawang putih sebagai perlakuan dilakukan dengan cara mengumpulkan kulit bawang dari pasar dan mengeringkannya. Kulit bawang yang telah kering dihaluskan menggunakan blender. Pakan yang digunakan pada penelitian menggunakan komposisi seperti yang disajikan pada Tabel 1.

Tabel 1. Komposisi dan kandungan nutrien pakan penelitian

\begin{tabular}{|c|c|c|c|c|c|c|c|}
\hline Bahan pakan & T0 & $\mathrm{T} 1$ & $\mathrm{~T} 2$ & T3 & T4 & $\mathrm{T} 5$ & T6 \\
\hline & \multicolumn{7}{|c|}{ 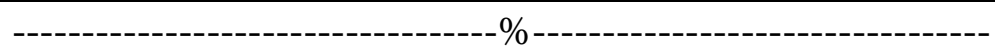 } \\
\hline Jagung giling & 44,5 & 44,5 & 44,5 & 44,5 & 44,5 & 44,5 & 44,5 \\
\hline Dedak padi & 19,2 & 19,2 & 19,2 & 19,2 & 19,2 & 19,2 & 19,2 \\
\hline Tepung ikan & 10,0 & 10,0 & 10,0 & 10,0 & 10,0 & 10,0 & 10,0 \\
\hline Bungkil kedelai & 24,0 & 24,0 & 24,0 & 24,0 & 24,0 & 24,0 & 24,0 \\
\hline $\mathrm{CaCO} 3$ & 1,3 & 1,3 & 1,3 & 1,3 & 1,3 & 1,3 & 1,3 \\
\hline Premix & 1,0 & 1,0 & 1,0 & 1,0 & 1,0 & 1,0 & 1,0 \\
\hline TKBM & 0,0 & 3,0 & 6,0 & 0,0 & 0,0 & 1,5 & 3,0 \\
\hline TKBP & 0,0 & 0,0 & 0,0 & 3,0 & 6,0 & 1,5 & 3,0 \\
\hline Total & 100,0 & 103,0 & 106,0 & 103,0 & 106,0 & 103,0 & 106,0 \\
\hline Protein kasar (\%) & 20,06 & 19,68 & 19,32 & 19,67 & 19,31 & 19,68 & 19,31 \\
\hline Lemak kasar (\%) ${ }^{\mathrm{a}}$ & 2,95 & 2,94 & 2,93 & 2,93 & 2,90 & 2,94 & 2,92 \\
\hline Serat kasar (\%) ${ }^{a}$ & 4,45 & 5,31 & 6,12 & 5,30 & 6,09 & 5,30 & 6,11 \\
\hline $\mathrm{EM}(\mathrm{Kkal} / \mathrm{kg})^{\mathrm{a}}$ & 2902 & 2881 & 2861 & 2884 & 1867 & 2882 & 2864 \\
\hline $\mathrm{Ca}(\%)^{\mathrm{a}}$ & 1,18 & 1,80 & 2,38 & 1,92 & 2,61 & 1,86 & 2,49 \\
\hline
\end{tabular}

Keterangan : ${ }^{a}$ Berdasarkan hasil analisis bahan pakan di Laboratorium Ilmu Nutrisi dan Pakan Universitas Diponegoro. 
Perlengkapan yang digunakan dalam penelitian ini antara lain kandang litter, kandang battery, tempat pakan dan minum, sekam, lampu, termometer, timbangan analitik, nampan dan plastik. Kandang yang digunakan sebagai tempat pemeliharaan adalah kandang littersebanyak 28 unit dengan ukuran 1,5 m $\mathrm{x}$ 0,5 m. Kandang battery yang digunakan untuk total koleksi juga sebanyak 28 buah. Itik diberi perlakuan pakan sebanyak 3 kali sehari, yaitu pada pagi, siang, dan sore hari selama 4 minggu pemeliharaan. Pemberian air minum dilakukan secara ad libitum.

Parameter yang diamati antara lain kecernaan protein kasar, pertambahan bobot badan dan persentase karkas. Data pertambahan bobot badan diambil dengan menimbang bobot awal itik (umur 4 minggu) pada hari pertama perlakuan dan ditimbang kembali setiap minggunya hingga minggu ke-4 perlakuan (umur 8 minggu). Perhitungan pertambahan bobot badan dilakukan dengan mengurangkan bobot akhir itik dengan bobot awal itik dibagi dengan lama pemeliharaan.

Pengambilan data persentase karkas dilakukan dengan mengambil sampel satu ekor itik dari tiap unit percobaan. Itik ditimbang bobotnya terlebih dahulu untuk mendapatkan bobot potong. Itik yang telah ditimbang, disembelih dan dikeluarkan darahnya. Langkah selanjutnya adalah proses karkasing hingga dihasilkan daging dan tulang tanpa bulu, kepala, leher, ceker, dan organ dalam (kecuali paru-paru dan ginjal). Daging dan tulang itik hasil karkasing ditimbang untuk mendapatkan bobot karkas. Rumus yang digunakan untuk menghitung persentase karkas adalah sebagai berikut:

Persentase karkas $=\frac{\text { Bobot karkas }}{\text { Bobot potong }} \times 100 \%$
Pengambilan data kecernaan
protein kasar dilakukan dengan menggunakan metode total koleksi menurut petunjuk Widodo dkk (2013), dengan menggunakan 28 itik yang diambil dari tiap unit percobaan. Total koleksi dilakukan setelah pemberian perlakuan selama 4 minggu selesai. Satu ekor itik tiap unit percobaan dimasukkan kedalam kandang battery dan dipuasakan selama 1 hari untuk mengosongkan isi saluran pencernaannya. Itik yang telah dipuasakan diberi pakan sesuai dengan perlakuan, ditampung ekskretanya selama 4 hari berturut-turut dan dipuasakan lagi selama 1 hari. Ekskreta yang ditampung dipisahkan tiap harinya dengan cara mengganti tempat penampungan ekskreta. Penyemprotan ekskreta menggunakan $\mathrm{HCl}$ 0,2 N dilakukan setiap 2 jam sekali. Ekskreta yang telah didapatkan ditimbang bobotnya dan dikeringkan hingga kering udara. Ekskreta dihaluskan hingga berbentuk tepung dan diukur kandungan protein kasarnya menggunakan metode Kjedahl. Rumus perhitungan nilai kecernaan protein kasar dari pakan adalah sebagai berikut:

Kecernaan protein kasar $=$

$\frac{\text { Konsumsi protein-Protein ekskreta }}{\text { Konsumsi protein }} \times 100 \%$

Penelitian ini menggunakan rancangan acak lengkap (RAL) dengan 7 perlakuan dan 4 ulangan, dimana tiap unit percobaan terdiri dari 6 ekor itik. Perlakuan pada pakan yang diberikan adalah:

$\mathrm{T} 0=$ Pakan basal

T1 =Pakan basal + 3\% tepung kulit bawang merah (TKBM)

$\mathrm{T} 2=$ Pakan basal $+6 \%$ tepung kulit bawang merah (TKBM)

T3 = Pakan basal $+3 \%$ tepung kulit bawang putih (TKBP) 


$$
\begin{aligned}
\mathrm{T} 4= & \text { Pakan basal }+6 \% \text { tepung kulit } \\
& \text { bawang putih }(\mathrm{TKBP}) \\
\mathrm{T} 5= & \text { Pakan basal }+1,5 \% \mathrm{TKBM}+ \\
& 1,5 \% \text { TKBP } \\
\mathrm{T} 6= & \text { Pakan basal }+3 \% \mathrm{TKBM}+3 \% \\
& \text { TKBP }
\end{aligned}
$$

\section{HASIL DAN PEMBAHASAN}

\section{Kecernaan protein kasar}

Hasil analisis ragam menunjukkan bahwa perlakuan penambahan tepung kulit bawang berpengaruh nyata $(\mathrm{P}<0,05)$ terhadap kecernaan protein kasar (Tabel 2). Berdasarkan uji Duncan, perlakuan T6 berbeda nyata dengan perlakuan T0, T1, dan T2, sedangkan perlakuan T4 berbeda nyata dengan perlakuan $\mathrm{T} 1$.

Penambahan tepung kulit bawang putih sebanyak 6\% (T4) dan kombinasi tepung kulit bawang merah sebanyak 3\% + tepung kulit bawang putih 3\% (T6) dapat memberikan pengaruh peningkatan kecernaan protein pakan yang lebih tinggi dibandingkan dengan pakan perlakuan lainnya. Hasil tersebut menunjukkan bahwa semakin banyak penambahan tepung kulit bawang pada pakan hingga taraf 6\% dapat meningkatkan kecernaan protein kasar. Hal ini disebabkan oleh peningkatan kandungan antioksidan dan antibakteri dalam pakan akibat penambahan tepung kulit bawang.

Tabel 2. Pengaruh perlakuan terhadap kecernaan protein kasar (PK), pertambahan bobot badan (PBB) dan persentase karkas itik Mojosari

\begin{tabular}{lccccccc}
\hline \multirow{2}{*}{ Parameter } & \multicolumn{7}{c}{ Perlakuan } \\
\cline { 2 - 8 } & T0 & T1 & T2 & T3 & T4 & T5 & T6 \\
\hline Kecernaan PK (\%) & $74,8^{\text {bc }}$ & $73,7^{\mathrm{c}}$ & $75,5^{\mathrm{bc}}$ & $78,0^{\mathrm{abc}}$ & $79,3^{\mathrm{ab}}$ & $78,1^{\mathrm{abc}}$ & $81,1^{\mathrm{a}}$ \\
PBB (g/ekor/hari) & $15,88^{\mathrm{c}}$ & $18,48^{\mathrm{ab}}$ & $18,42^{\mathrm{ab}}$ & $17,96^{\mathrm{ab}}$ & $19,77^{\mathrm{a}}$ & $17,30^{\mathrm{bc}}$ & $19,05^{\mathrm{ab}}$ \\
Persentase karkas (\%) & 55,90 & 53,98 & 55,98 & 54,91 & 55,17 & 55,27 & 56,64 \\
\hline Keterangan:
\end{tabular}

Keterangan: Huruf superskrip yang berbeda menunjukkan perbedaan yang nyata $(\mathrm{P}<0,05)$

Kulit bawang merah dan bawang putih memiliki kandungan flavonoid dan organosulfur yang berperan sebagai antioksidan dan antibakteri. Hedges dan Lister (2007) menyatakan bahwa flavonoid, fructans, organosulfur, dan saponin merupakan komponen fitokimia yang terdapat pada bawang (Allium). Hanen et al. (2012) menambahkan bahwa komponen antioksidan pada bawang paling besar berasal dari phenolic, flavonoid dan vitamin $C$, sedangkan organosulfur memiliki peran penting sebagai antibakteri.

Hasil penelitian ini juga menunjukkan bahwa pakan yang mendapat penambahan tepung kulit bawang putih (T3, T4, T5, dan T6) memiliki kecernaan protein kasar lebih tinggi dibandingkan dengan pakan basal (T0) dan pakan yang hanya mendapat penambahan tepung kulit bawang merah saja (T1 dan T2). Hal ini dikarenakan oleh tingginya kandungan antibakteri pada tepung kulit bawang putih. Hanen et al. (2012) menyatakan bahwa komponen antibakteri paling besar dari bawang putih berasal dari organosulfur yang berupa Allicin.

Kandungan antibakteri yang tinggi pada tepung kulit bawang putih dapat menghambat pertumbuhan bakteri patogen sehingga penyerapan nutrien dan antioksidan menjadi lebih baik. Hedges dan Lister (2007) menyatakan bahwa kandungan antimikrobia pada 
bawang putih dapat menghambat Clostridioum, Bacillus, Escherichia, Micrococcus, Mycobacterium, Pseudomonas, Salmonella, Staphylococcus, Streptococcus, dan beberapa lainnya. Bawang merah memiliki kandungan antioksidan yang lebih tinggi daripada kandungan antibakterinya. Skerget et al. (2009) menyatakan bahwa secara umum bawang merah memiliki kandungan antioksidan berupa phenolic dan flavonoid yang lebih banyak daripada bawang putih. Kandungan antibakteri yang kecil pada bawang merah dapat membuat peran antibakteri menjadi tidak efektif, sehingga penyerapan nutrien dan antioksidan tidak bekerja secara maksimal.

Penambahan tepung kulit bawang putih pada pakan yang dikombinasikan dengan penambahan tepung kulit bawang merah tetap meningkatkan kecernaan protein kasar pakan. Hal tersebut disebabkan oleh kandungan antibakteri dan antioksidan yang seimbang pada kombinasi tepung kulit bawang merah dan bawang putih. Hedges dan Lister (2007) menyatakan bahwa semua spesies dengan genus Allium memiliki komponen yang sama namun dengan kadar dan struktur yang berbeda. Penambahan tepung kulit bawang merah dan bawang putih secara bersamaan akan menyeimbangkan peran antibakteri dan antioksidan dalam saluran pencernaan. Kandungan antibakteri pada kulit bawang menghambat pertumbuhan bakteri patogen dalam saluran pencernaan, sehingga nutrien hasil pencernaan dapat diserap dengan baik. Antioksidan yang terserap akan membantu pencegahan oksidasi pada sel-sel saluran pencernaan sehingga sel-sel di saluran pencernaan menjadi lebih sehat dan penyerapan nutrien menjadi semakin baik. Penyerapan nutrien yang tinggi pada saluran pencernaan meningkatkan kecernaan protein kasar pakan. Hal ini sesuai dengan pendapat Sukary- ana dkk (2011) yang menyatakan bahwa kecernaan dapat dipengaruhi oleh tingkat pemberian pakan, jenis pakan, spesies hewan, cara pengolahan pakan, dan kesehatan saluran pencernaan.

\section{Pertambahan bobot badan}

Hasil analisis ragam menunjukkan bahwa pemberian perlakuan penambahan kulit bawang berpengaruh nyata $(\mathrm{P}<0,05)$ terhadap pertambahan bobot badan itik Mojosari. Berpengaruhnya perlakuan terhadap pertambahan bobot badan itik berbanding lurus dengan peningkatan konsumsi pakan, konsumsi protein dan kecernaan protein kasar yang menunjukkan terjadinya peningkatan penyerapan protein. Protein yang diserap akan dimanfaatkan untuk pembentukan daging sehingga pertambaan bobot badan pada itik menjadi lebih tinggi. Herdiana dkk (2014) menyatakan bahwa protein merupakan komponen yang paling banyak diperlukan dalam pembentukan jaringan tubuh.

Penambahan kulit bawang pada pakan secara umum meningkatkan konsumsi pakan itik Mojosari. Peningkatan konsumsi pakan secara umum juga menyebabkan peningkatan protein yang terkonsumsi. Konsumsi pakan, konsumsi protein dan konsumsi EM dapat dilihat pada Tabel 3.

Kandungan antibakteri dan antioksidan yang tinggi pada kulit bawang mampu meningkatkan kesehatan unggas, terutama pada saluran pencernaan. Hanen et al. (2012) menyatakan bahwa bawang merupakan tanaman obat yang sudah biasa digunakan di masyarakat dan mengandung komponen bioaktif. Hedges dan Lister (2007) menyatakan bahwa kandungan fitokimia dalam bawang dapat meningkatkan kesehatan pada saluran pencernaan. 


$\begin{array}{ll}\text { Penambahan tepung kulit } & \text { yang terserap inilah yang nantinya } \\ \text { bawang pada pakan dengan taraf } & \text { digunakan untuk memenuhi kebutuhan } \\ \text { tertentu terbukti dapat meningkatkan } & \text { maintenance tubuh, kebutuhan untuk } \\ \text { kecernaan protein pada itik (Tabel 2). } & \text { bertumbuh, dan kebutuhan untuk ber- } \\ \text { Itik yang memiliki saluran pencernaan } & \text { produksi. }\end{array}$
yang sehat akan mampu menyerap nutrien dalam pakan dengan baik. Nutrien

Tabel 3. Rataan konsumsi ransum dan konsumsi nutrien harian

\begin{tabular}{lrrc}
\hline Perlakuan & Konsumsi pakan & Konsumsi protein & Konsumsi EM \\
\hline T0 & --------- gram------- & -- KKal--- \\
T1 & $78,07^{\mathrm{c}}$ & 15,66 & $226,57^{\mathrm{c}}$ \\
T2 & $78,71^{\mathrm{c}}$ & 15,49 & $226,77^{\mathrm{c}}$ \\
T3 & $83,44^{\mathrm{a}}$ & 16,12 & $238,73^{\mathrm{a}}$ \\
T4 & $80,55^{\mathrm{bc}}$ & 15,84 & $232,30^{\mathrm{abc}}$ \\
T5 & $83,41^{\mathrm{a}}$ & 16,11 & $239,14^{\mathrm{a}}$ \\
T6 & $80,31^{\mathrm{bc}}$ & 15,80 & $231,44^{\mathrm{bc}}$ \\
\hline
\end{tabular}

Keterangan: Huruf superskrip yang berbeda menunjukkan perbedaan yang nyata $(\mathrm{P}<0,05)$

\section{Persentase karkas}

Berdasarkan hasil analisis ragam didapati bahwa penambahan tepung kulit bawang merah dan bawang putih tidak memberikan pengaruh secara nyata $(\mathrm{P}>0,05)$ terhadap persentase karkas itik.

Kandungan antibakteri dan antioksidan pada kulit bawang diharapkan dapat meningkatkan kesehatan saluran percernaan, sehingga terjadi peningkatan kecernaan protein dan pertambahan bobot badan itik yang akan mempengaruhi persentase karkas. Hedges and Lister (2007) menyatakan bahwa bawang memiliki kandungan fitokimia yang dapat meningkatkan kesehatan pada saluran pencernaan. Hasil penelitian ini menunjukkan bahwa perlakuan memberikan pengaruh peningkatan pada kecernaan protein dan pertambahan bobot badan, namun tidak nyata meningkatkan persentase karkas itik.
Hasil persentase karkas yang hampir sama pada setiap perlakuan diduga disebabkan karena adanya peningkatan bobot organ dalam, kususnya bobot saluran pencernaan. Rataan bobot organ dalam dari T0 sampai T6 secara berurutan yaitu 150,8 g; 155,8 g; 164,0 g; 161,2 g; 160,0 g; 162,2 g; dan 160,2 g.

Peningkatan kandungan serat kasar pada pakan akibat penambahan tepung kulit bawang menyebabkan organ pencernaan bekerja lebih keras untuk mencerna. Aktifitas yang semakin berat pada saluran pencernaan ini memacu perkembangan jaringan pada organ pencernaan sehingga semakin tebal dan besar ukurannya. Has dkk (2014) menyatakan bahwa kandungan serat kasar yang tinggi pada pakan akan memperberat kerja organ pencernaan sehingga terjadi perubahan morfologi yang ditandai dengan peningkatan berat dan ukuran organ pencernaan. Protein yang tercerna dari pakan akan diguna- 
kan untuk pembentukan jaringan pada tubuh, termasuk jaringan organ pencernaan. Dewanti dkk (2013) menyatakan bahwa protein memiliki peran penting dalam pembentukan jaringan. Hal ini menyebabkan pertambahan bobot pada organ pencernaan yang termasuk dalam bagian non karkas. Oleh karena itu, peningkatan kecernaan protein belum dapat memberikan pengaruh secara nyata terhadap persentase karkas itik.

\section{KESIMPULAN DAN SARAN}

Penambahan tepung kulit bawang putih $6 \%$ dan kombinasi tepung kulit bawang merah 3\% + tepung kulit bawang putih $3 \%$ mampu meningkatkan kecernaan protein kasar pakan dan pertambahan bobot badan, namun belum dapat meningkatkan persentase karkas pada itik Mojosari. Oleh karena itu, penelitian ini menyarankan untuk melakukan investigasi lebih lanjut tentang penggunaan ekstrak kulit bawang dan penurunan kandungan serat kasar dalam pakan sehingga diharapkan terjadi peningkatan terhadap persentase karkas itik.

\section{DAFTAR PUSTAKA}

Dewanti, R., M. Irham dan Sudiyono. 2013. Pengaruh penggunaan enceng gondok (Eichornia crassipes) terfermentasi dalam pakan terhadap persentase karkas, non-karkas, dan lemak abdominal itik lokal jantan umur delapan minggu. Buletin Peternakan 37(1):19-25.

Hanen, N., S. Fattouch, E. Ammar and M. Neffati. 2012. Allium species, ancient health food for the future?

(http://www.intechopen.com/boo ks/scientific-health-and-socialaspects-of-the-foodindustry/allium-species-ancient- health-food-for-the-future-). Diakses: 2 Maret 2016.

Has, H., A. Napirah dan A. Indi. 2014. Efek peningkatan serat kasar dengan penggunaan daun murbei dalam ransum broiler terhadap persentase bobot saluran pencernaan. JITRO 1(1):63-69.

Hedges, L. J. and C. E. Lister. 2007. The nutritional attributes of allium species. Crop dan food research confidential report, New Zealand.

(http://www.vegetables.co.nz/res ources/1files/pdf/booklet_onion leek_garlic foodreport.pdf). Diakses pada tanggal 2 Maret 2016.

Herdiana, R. M., Y. Marshal, R. Dewanti dan Sudiyono. 2014. Pengaruh penggunaan ampas kecap dalam pakan terhadap pertambahan bobot badan harian, konversi pakan, rasio efisiensi protein, dan produksi karkas itik lokal jantan umur delapan minggu. Buletin Peternakan 38(3):157-162.

Saleh, E., T. Hestiwahyuni, dan G. P. Saragih. 2006. Pemberian tepung bawang putih (Allium sativum L.) dalam pakan terhadap performans itik Peking umur 1-8 minggu. J. Agribisnis Peternakan 2(3):96-100.

Skerget, M., L. Majhenie, M. Bezjak, and Z. Knez. 2009. Antioxidant, radical scavenging and antimicrobial activities of red onion (Allium cepa L.) skin and edible part extracts. Chem. Biochem. Eng. Q. 23(4):435-444.

Sukaryana, Y., U. Atmomarsono, V. D. Yunianto, dan E. Supriyatna. 2011. Peningkatan nilai kecernaan protein kasar dan lemak kasar produk fermentasi campuran bungkil inti sawit dan 
dedak padi pada broiler. JITP. 1(3):167-172.

Widodo, A. R., H. Setiawan, Sudiyono, Sudibya, dan R. Indreswari. 2013. Kecernaan nutrien dan performa puyuh (Coturnix coturnix japonica) jantan yang diberi ampas tahu fermentasi dalam pakan. Tropical Animal Husbandry 2(1):51-5. 